\title{
Sidamo Language
}

National Cancer Institute

\section{Source}

National Cancer Institute. Sidamo Language. NCI Thesaurus. Code C154115.

An Afro-Asiatic language, belonging to the Highland East Cushitic branch of the Cushitic family spoken in parts of southern Ethiopia by the Sidama people. 